\title{
Dakwah Muhammadiyah dalam Membangun Kesadaran Nasional di Kendari Masa Pra Kemerdekaan: Perspektif Gerakan Sosial
}

\author{
Muhammad Alifuddin \\ IAIN Kendari \\ proposalalif@gmail.com
}

\begin{abstract}
This study aims to provide an analytical description of Muhammadiyah Da'wah in Building National Awareness in Kendari in the Pre-Independence Period in terms of a social movement perspective. This research data is generally sourced from literature and interviews. All data obtained were studied in stages using historical analysis models. The historical data found shows that Muhammadiyah has existed in Kendari in 1930. The active involvement of Muhammadiyah elements in arousing the spirit of nationalism in the pre-independence era, apart from being a social responsibility of Muhammadiyah members as an integral part of the Indonesian people, is also due to the strong organizational doctrine that is manifested in the vision of Muhammadiyah members, namely as the driving subject of the da'wah of amar makruf nahi mungkar. This doctrine is the foundation in transmitting the idea of a national awakening in Kendari through organized dakwah and tabligh movements. At first, Muhammadiyah actors were active in channeling the spirit of Islam and nationalism openly. However, the main character driving the Muhammadiyah was given the status of persona non grata by the colonial party, so the Muhammadiyah dakwah movement was then carried out in a klendestin (underground movement). This last approach was taken considering that the political structure of the pre-independence era was closed and hegemonic, making it less conducive to "transmitting" ideas of nationalism to the public or the subject of open propaganda. Recognition of the significant role of Muhammadiyah's da'wah movement in instilling awareness of Nationalism in Kendari is objectively recorded in the document of the History of the National Awakening of the Southeast Sulawesi Region.
\end{abstract}

Keywords: Da'wah, National Awakening, Social Movement 


\begin{abstract}
Abstrak
Penelitian ini bertujuan memberikan gambaran analitik tentang Dakwah Muhammadiyah dalam Membangun Kesadaran Nasional di Kendari Masa Pra Kemerdekaan di Tinjau dari Perspektif Gerakan Sosial. Data penelitian ini umumnya bersumber data kepustakaan dan wawancara. Seluruh data yang diperoleh dikaji secara berjenjang dengan menggunakan model analisis sejarah. Data sejarah yang ditemukan menunjukkan bahwa Muhammadiyah telah bereksistensi di Kendari pada tahun 1930. Keterlibatan aktif elemen Muhammadiyah dalam membangkitkan semangat nasionalisme pada masa pra kemerdekaan, selain sebagai tanggungjawab sosial warga Muhammadiyah selaku bagian tak terpisahkan dari rakyat Indonesia, juga disebabkan kuatnya doktrin persyarikatan yang mengejawantah dalam visi anggota Muhammadiyah, yaitu sebagai subyek penggerak dakwah amar makruf nahi mungkar. Doktrin inilah yang menjadi fondasi dalam mentransmisikan gagasan kebangkitan nasional di Kendari melalui gerakan dakwah dan tabligh yang terorgansir. Giat mengalirkan semangat Islam dan nasionalisme oleh aktor-aktor Muhammadiyah pada mulanya dilakukan secara terang-terangan. Namun tokoh utama penggerak Muhammadiyah diberi status persona non grata oleh pihak colonial, maka gerakan dakwah Muhammadiyah selanjutnnya dilakukan secara klendestin (gerakan bawah tanah). Pendekatan terakhir ini ditempuh mengingat ruang struktur politik pada masa pra kemerdekaan bersifat tertutup dan hegemonik, sehingga kurang kondusif untuk "menularkan" ide-ide nasionalisme kepada masyarakat atau subyek dakwah secara terbuka. Pengakuan atas peran signifikan gerak dakwah Muhammadiyah dalam menanamkan kesadaran Nasionalisme di Kendari secara obyektif tercatat dalam dokumen Sejarah Kebangkitan Nasional Daerah Sulawesi-Tenggara.
\end{abstract}

\title{
Kata kunci: Dakwah, Kebangkitan Nasional, Gerakan Sosial
}

\section{A. Latar Belakang}

Peran sentral tokoh-tokoh Muhammadiyah membangun dan mengawal kedaulatan Indonesia tidak diragukan lagi. Sejumlah tokoh nasional lahir dari rahim organ ini, mereka antara lain: Ir Soekarno (Proklamator RI), Jenderal Soedirman, Ki Bagus Hadikusumo, Prof. Abdul Kahar Muazakkir, KH.Mas Masur, Kasman Singadimeja, Muhammad Roem, Juanda serta sejumlah tokoh nasional yang tidak dapat disebutkan satu persatu. Berbagai penelitian sejarah yang dilakukan oleh para ahli dalam dan luar negeri memberi bukti konkrit tentang peran signifikan Muhammadiyah dalam merebut kemerdekaan 
(Ricklefs,2005:306). Namun demikian penelitian terkait peran Muhammadiyah bagi kemerdekaan dalam konteks lokal, sangat jarang atau sulit untuk ditemukan.

Berangkat dari kenyataan tersebut, maka penelitii tertarik untuk menelusuri rekam jejak dakwah Muhammadiyah di Kota Kendari dalam hubungannya dengan semangat membangun nasionalisme sebelum masa kemerdekaan dalam bingkai perspektif gerakan sosial (social movement theory). Penelitian ini menjadi urgen, selain karena data dari fakta sejarah tentang peran dan jasa umat Islam khususnya Muhammadiyah banyak yang tidak diketahui oleh umat Islam, juga adanya realitas politik yang mengarah pada upaya pengaburan peran sejarah umat Islam. Karena itu pilihan tema penelitian ini sengaja diangkat guna memahamkan generasi muda negeri ini tentang peran Muhammadiyah dalam membangkitkan kesadaran Nasional di Kota Kendari. Jika dalam konteks nasional peran Muhammadiyah dalam membangkitkan kesadaran nasional melalui keterlibatan para tokohnya tidak dapat diragukan, maka pertanyaannya kemudian adalah apakah dalam konteks regional kehadiran Muhammadiyah juga menjadi jembatan dalam membangun kesadaran nasional. Melalui penelitian ini akan diungkap bagaimana peran Muhammadiyah dalam mendorong kebangkitan Nasional di Kota Kendari. Selain itu itu, juga akan ditelaah bagaimana pola aktivitas yang dikembangkan oleh organ Muhammadiyah dalam membangkitkan kesadaran nasional masyarakat di daerah ini.

\section{B. Metode Penelitian}

Penelitian ini bersifat deskriptif analitik dengan menggunakan data-data kualitatif. Karena penelitian ini adalah upaya memotret realitas Muhammadiyah dalam ruang sosial budaya dan sejarah, maka meniscayakan peneliti untuk menaati mekanisme dan proseudur kerja sejarah. Data primer penelitian ini berasal dari data-data tertulis berupa dokumen seperti; arsip pemerintah dan organisasi terkait, hasil penelitian, buku, surat kabar, majallah dan lain-lain. Selain itu penulis juga melakukan wawancara kepada sejumlah tokoh Muhammadiyah serta para pihak yang memahami fokus penelitian ini. Seluruh 
data yang diperoleh dianalisis melalui mekanisme: heuristik, kritik, intrepretasi dan historiografi. (Notosutanto,1978: 23-24)

\section{Hasil Penelitian dan Pembahasan \\ C.1 Sketsa Muhammadiyah Kendari Periode Pra Kemerdekaan}

Secara historis diketahui bahwa Muhammadiyah pertama kali dibentuk oleh KH.Ahmad Dahlan di Yogyakarta pada tahun 1912 (Noer, 1996: 85). Dengan melihat tahun terbentuknya, secara kasat mata dapat disimpulkan bahwa eksistensi organ bentukan Ahmad Dahlan ini telah berinteraksi dengan masyarakat Indonesia umumnya dan umat Islam khususnya sejak masa sebelum kemerdekaan. Ditinjau dari sisi waktu keberadaannya, maka Muhammadiyah telah bereksistensi 33 tahun lebih awal di bumi Nusantara sebelum Indonesia berdaulat sebagai sebuah Negara. Karena itu, dari sisi politik dan komitmen kebangsaan, keterlibatan Muhammadiyah untuk membangun dan memperkuat aras integrasi baik sebelum dan sesudah Indonesia merdeka tidak dapat diragukan.

Sekalipun pada masa awal pembentukannya organ Muhammadiyah lebih berkonsentrasi di sekitar kepuluan Jawa, namun tuntutan dakwah Islam menjadikan organ ini kemudian menjadi tersebar hingga ke Sumatera, Sulawesi, Kalimantan hingga ke ujung paling Timur dari kepulan Nusantara (Papua). Gerak Muhammadiyah yang melintasi batas kepuluan Jawa adalah sebuah keniscayaan yang tak dapat dihindari. Paling tidak ada dua alasan yang dapat dikemukan bagi realitas tersebut. Pertama: para pendiri awal Muhammadiyah umumnya adalah para pedagang yang meniscayakan mereka bergerak ke ruang yang lebih luas dalam rangka mempromosikan gagasan Islam berkemajuan. Kondisi tersebut mengharuskan mereka tidak hanya menetap pada satu kantong wilayah tertentu tetapi niscaya berkeliling atau bahkan melintasi samudera. Kesempatan mengelilingi berbagai wilayah oleh para kader Muhammadiyah tidak saja dimanfaatkan untuk berdagang tetapi juga sekaligus dijadikan kesempatan untuk memperkenalkan Muhammadiyah pada setiap tempat dimana kaki mereka 
dipijakkan. Hal ini susai dengan teoresasi de Graf yang menyebutkan bahwa Islamisasi di Indonesia banyak diperankan oleh para pedagang (De Graf,1970:123). Kedua: sebagai organisasi dakwah yang bertujuan memberikan pencerahan pemahaman agama kepada masyarakat, Muhammadiyah tentu saja tidak bisa hanya tinggal diam di tempat, menunggu jamaah untuk mengetuk pintupintu madrasahnya, tetapi niscaya bagi Muhammadiyah untuk menyapa subyek dakwahnya. Dan bagi Muhammadiyah yang meletakkan dakwah sebagai salah satu amanah, meniscayakan mereka untuk mengorganisasikan kegiatan dakwah dalam rangka mendekatkan umat pada agama yang diyakininya. Dalam konteks itulah sejak awal masa keberadaannya Muhammadiyah mengutus atau mengirim para kadernya di sejumlah daerah sebagai anak panah Muhammadiyah, dengan tugas memberikan pengajaran Islam plus mengembangkan Muhammadiyah. (Haedar: 2018)

Tekad kuat kader Muhammadiyah untuk menyinari bumi pertiwi dengan sinar terang matahari bertujuan untuk memberdayakan masyarakat melalui gerakan dakwah, pendidikan dan layanan sosial. Dalam konteks masa awal pembentukannya, gerakan sosial dan layanan pendidikan sangatlah dibutuhkan oleh masyarakat, mengingat pada masa tersebut layanan pendidikan masih bersifat eksklusif yang hanya dapat diakses oleh kelompok masyarakat tertentu. Kehadiran Muhammadiyah yang menegosiasikan layanan sosial bagi pencerahan akal budi oleh sebagian masyarakat diapresiasi dengan cara mendirikan ranting dan cabang Muhammadiyah di berbagai daerah di Indonesia, sehingga tanpa harus menunggu waktu yang lama gerakan ini berdiri di hampir seluruh wilayah Nusantara. ( Hasbullah,1995: 95)

Pelintasan organ ini ke jazirah Sulawesi Tenggara, seperti Buton, Muna, Kolaka, dan Kendari terjadi dalam waktu yang hampir bersamaan yaitu dalam rentan waktu 1928-1930. Dari sumber sejarah yang ditemukan, dapat diketahui bahwa gerak melintas Muhammadiyah disalurkan oleh anak-anak panah Muhammadiyah dari beragam profesi. Secara umum agent Muhammadiyah masa awal di wilayah ini dilakukan oleh para pegawai pemerintahan yang ditugaskan ke 
wilayah ini (umumnya para guru) serta para pedagang yang bermigrasi untuk mengais hidup sekaligus melakukan tugas dakwah. Melalui jasa para pegawai pemerintahan, guru dan para pedagang, visi dan misi Muhammadiyah dimasukkan ke wilayah ini dengan beragam pendekatan dan metode (Depdikbud,1978: 90).

Orientasi Muhammadiyah sebagai gerakan dakwah amar-makruf nahi mungkar bertemu dengan kondisi sosial politik dan budaya yang dialami oleh bangsa Indonesia sebelum masa kemerdekaan, diyakini memberikan pengaruh yang besar bagi lahirnya semangat juang anak-anak Muhammadiyah untuk menanamkan pengaruhnya. Dengan merujuk pada data awal kehadiran Muhammadiyah di sekitar tahun 1928-1930 menunjukkan bahwa kehadiran Muhammadiyah di jazirah Tenggara pulau Sulawesi ini, selain bertujuan melebarkan sayap pengaruh Muhammadiyah juga terkait erat dengan semangat nasionalisme anak-anak Muhammadiyah untuk membuka dan atau memutus mata rantai belenggu yang diikatkan oleh penjajah Belanda pada waktu itu. Atau dengan kata lain misi dakwah oleh para agen Muhammadiyah pada waktu itu digandengkan dengan semangat anti penjajahan. Hal ini sesuai dengan pandangan Ricklefs yang menyebutkan bahwa Muhammadiyah umumnya memberi kontribusi signifikan atas kemunculan pemuda yang berjiwa merdeka, berakidah Islam, sanggup menentang hegemoni penjajahan Belanda dan Jepang, sehingga tidak bisa disangkal bahwa keberhasilan kemerdekaan Indonesia salah satunya berkat perjuangan kaum Muhammadiyah. (Ricklefs :306).

Kehadiran anak panah Muhammadiyah di wilayah ini, dengan membawa misi pencerahan bagi masyarakat bersetuju dengan harapan warga Nusantara yang mengimpikan kemerdekaan atau keluar dari belenggu penjajahan Belanda. Sebagai bagian integral dari wilayah kerajaan-kerajaan Nusantara, masyarakat yang mendiami pulau-pulau dan daratan di Sulawesi-Tenggara sebagaimana masyarakat Nusantara lainnya memiliki hasrat dan cita-cita yang kuat untuk menjadi satu entitas sosial politik yang kuat dan berdaulat di dalam Negara dan bangsanya. Dalam konteks itulah timbul kesadaran untuk bersatu padu dalam satu 
kekuatan politik Negara bangsa yang pada masa selanjutnya disebut Negara Kesatuan Republik Indonesia. Tampaknya semangat itupula yang mengantar anak-anak panah Muhammadiyah yang berasal dari berbagai daerah, untuk mengambil bagian dan peran signifikan dalam pergerakan kebangkitan Nasional melalui jalur dakwah Muhammadiyah di Sulawesi-Tenggara.

Kehadiran Muhammadiyah di Sulawesi-Tenggara pada masa sebelum kemerdekaan masuk dari berbagai jalur atau dengan kata lain masuknya organ ini ke wilayah Sulawesi-Tenggara, entah direncanakan atau tidak, masuk secara bersamaan di wilayah onder afdeeling. Perlu dicatat bahwa nama SulawesiTenggara sebagai satu wilayah politik administrative/propinsi baru terjadi pada masa setelah kemerdekaan dan merupakan pemekaran dari Propinsi SulawesiSelatan. Meski demikian "Sulawesi Tenggara" sebagai istilah geografis telah dikenal, sejak abad XIX. A. Ligtvoet dalam bukunya Beschrijving en Gesch iedents van Boeton (1877) menyebutkan jazirah Sulawesi-Tenggara (Het Zuidoostelijk schiereiland van Celebes). Kemudian Paul dan Frits Sarasin menulis Reise von der Miengkoka Baai nach Kendari, Sudost Celebes pada 1903 dan Dr. Alb. C Kruyt menulis Een en Ander over de Tolaki van Mekongga (Zuidoost Celebes) pada 1922. Istilah geografis Sulawesi-Tenggara atau Jazirah Tenggara Sulawesi ini meliputi pulau-pulau sekitarnya utamanya pulau-pulau besar di sebelah selatan, yaitu Buton, Muna dan Kabaena. Sulawesi-Tenggara menjadi istilah politik (pemerintahan) sejak 1951 ketika Afdeeling Buton dan Laiwui dirubah menjadi Daerah Sulawesi Tenggara dengan Bau-Bau sebagai Ibu Kota. Dalam pengertian pemerintahan, Sulawesi Tenggara meliputi pulau-pulau di sekitarnya, sehingga secara geografis Sulawesi Tenggara dapat dibedakan antara daratan (Kabupaten Kendari dan Kolaka) dan kepulauan (Kabupaten Buton dan Muna). Mengingat secara geografis wilayah Sulawesi-Tenggara terdiri dari atau dapat dibagi kedalam dua wilayah besar, yaitu wilayah daratan maka realitas Muhammadiyah Sulawesi-Tenggara sebelum masa kemerdekaan juga terbagi pada wilayah yaitu: Muhammadiyah di wilayah daratan yang meliputi Kendari dan Kolaka serta Muhammadiyah di wilayah kepuluan yaitu Buton dan Muna. 
Catatan sejarah yang ditemukan menjelaskan bahwa pembentukan Muhammadiyah di wilayah Sulawesi-Tenggara baik di wilayah daratan maupun kepuluan umumnya diperankan oleh kader-kader Muhammadiyah yang berasal dari Sulawesi-Selatan yang berkolaborasi dengan anak-anak daerah yang memiliki minat ber-Muhammadiyah. Jika dikaji berdasarkan data-data sejarah tertulis yang ditemukan, maka pembentukan Muhammadiyah di Sulawesi-Tenggara banyak diperankan oleh para pegawai yang ditugaskan ke wilayah ini. Di Kendari, kehadiran Muhammadiyah awalnya juga diinisiasi oleh seorang pegawai Belanda yang ditugaskan sebagai seorang guru di Kota ini. Dalam dokumen Sejarah Kebangkitan Nasional Daerah Sulawesi Tenggara disebutkan, bahwa Muhammadiyah telah menancapkan pengaruhnya di Kendari sekitar tahun 1929/30-an. Adalah Ahmad Makkarausu Dg. Ngilau seorang guru yang sebelumnya bertugas di Bau-Bau kemudian dipindah tugaskan ke Kendari sebagai salah satu subyek yang mempelopori berdirinya Muhammadiyah di Kendari. Dg. Ngilau dikenal sebagai sosok kader Muhammadiyah yang mewakafkan dirinya untuk membangun Muhammadiyah pada setiap kehadirannya di suatu wilayah. Kehadiran Ahmad di Kendari adalah kehadiran yang sebelumnya tidak direncanakan, karena yang bersangkutan sebenarnya seorang guru yang ditugaskan dari Makassar ke Bau-Bau. (Khittah, 2016: 4). Di Bau-Bau Ahmad menkampanyekan Muhammadiyah pada masyarakat Buton. Karena dakwah Ahmad yang memadukan antara semangat Islam dan Nasionalisme oleh pemerintah Belanda dipandang dapat memicu kesadaran nasionalisme bagi masyarakat Buton, sedangkan bagi pihak kesultanan dakwah Dg. Ngilau dinilai bertentangan dengan aliran Islam mainstream, maka Dg. Ngilau kemudian dipindahkan ke Kendari (Ibid).

Pemindahan Ahmad Makkarausu Dg. Ngilau ke Kendari membuka pintu bagi kehadiran Muhammadiyah di wilayah ini. Sebagai seorang kader dan anak panah Muhammadiyah, pemindahannya ke Kendari tidak menjadikannya lesu darah, tetapi tempat tersebut juga dijadikan medan dakwah dan perjuangan untuk menanam bibit pohon Muhammadiyah di Kota yang belakangan ditetapkan 
sebagai Ibu Kota Propinsi Sulawesi-Tenggara. Di tempat ini Dg. Ngilau berkolaborasi dengan beberapa kader Muhammadiyah sehingga pada akhirnya di tahun 1930 terbentuklah kepungurusan Muhammadiyah di Kota Kendari dengan susunan sebagai berikut:

$\begin{array}{ll}\text { Ketua Umum } & \text { : Akhmad Makkarausu Dg. Ngilau (guru). } \\ \text { Sekretaris I } & : \text { Danu Hasan (Klerk swapraja Laiwui) } \\ \text { Sekretaris II } & : \text { Muhammad Kasim Maddualeng (swasta) } \\ \text { Komisaris } & : \text { Iwana (Kepala Distrik), } \\ & \text { H. Abd. Rachman Daud, } \\ & \text { Abd.Chalik } \\ & \text { M. Idris Dg. Macigi } \\ \text { Adviseur } & : \text { Sarbani (Landbouw opzichter) (ibid). }\end{array}$

\section{C.2 Aktivitas Muhammadiyah Kendari: Pra Kemerdekaan}

Setelah Muhammadiyah resmi terbentuk, maka organ ini melalui kader dan pengurusnya kemudian melakukan langkah produktif dalam rangka menggalang anggota untuk bergabung dengan Muhammadiyah. Bagi Dg. Ngilau yang berprofesi sebagai seorang guru, tidak mengalami banyak kendala untuk menanamkan pengaruh Muhammadiyah di Kendari. Perpaduan antara pengalaman dan militansi yang dimiliki Dg. Ngilau dalam mengurus persyarikatan Muhammadiyah, membuat organ ini dalam waktu tidak begitu lama mendapat sokongan dan pengikut dari beberapa tokoh masyarakat. Dengan modal dukungan para tokoh tersebut kemudian Muhammadiyah mewujud sebagai organisasi yang mantap. Setelah kepengurusan Muhammadiyah terbentuk, maka setidaknya ada dua kegiatan yang dilakukan oleh Muhammadiyah, yaitu rekruitmen keanggotaan dan menyelenggarakan kegiatan tabligh atau pengajian. Mengingat situasi politik yang tidak kondusif, maka rekruitmen keanggotaan dilakukan dengan sangat hati-hati dan teliti, hal ini dilakukan sebagai antisipasi atas kemungkinan adanya penyusup yang sengaja masuk untuk mengintai dan mematai-matai kegiatan Muhammadiyah. Sementara itu, terkait dengan kegiatan 
tabligh atau dakwah maka dilakukan secara lebih terbuka Muhammadiyah dan terjadual dua kali seminggu, yaitu setiap malam Ahad dan Rabu.(Depdikbud, 1978: 89).

Sebagai kader progresif, Akhmad Makkarausu Dg. Ngilau gencar menkampanyekan pembaruan Islam (Khittah,2016) dan memompakan isu serta semangat nasionalisme bagi masyarakat muslim di Kendari. Gagasan nasionalisme sebagai satu doktrin politik bertujuan membangkitkan perasaan kepemilikan dan hak atas tanah air dipadukan dengan semangat dakwah amar makruf nahi mungkar yang menjadi doktrin Muhammadiyah (SM,2016). Tematema dakwah yang mengusung doktrin Islam dan nasionalisme digaunkan oleh Ahamad dan kawan-kawannya berhasil memicu lahirnya visi dan kesadaran nasionalisme masyarakat. Namun demikian, aktifitas Ahmad yang menggawangi Muhammadiyah dinilai kontra produktif oleh pemerintah kolonial Belanda. Dalam dokumen Sejarah Kebangkitan Nasional Daerah Sulawesi-Tenggara disebutkan sebagai berikut:

Karena tabligh-tablighnya yang radikal dan berbau politik Muhammadiyah Kendari mengalami pengawasan ketat dari Belanda malah diberi catatan merah. Setiap tablighnya dihadiri oleh inteljen Belanda. Malah pengurus-pengurusnya diancam untuk ditindaki dan diberi peringatan keras (Depdikbud:90).

Sebagaimana telah disebutkan sebelumnya Ahmad Makkarausu ditugaskan ke wilayah ini sebagai seorang guru. Tampaknya profesi Ahmad sebagai seorang guru atau pendidik telah memberi ruang padanya untuk lebih leluasa menegosiasikan semangat Islam dalam visi Muhammadiyah plus semangat nasionalisme kepada masyarakat. Kondisi tersebut tentu saja bagi pihak Belanda merupakan ancaman serius, dan karena itu aktivitas Ahmad yang beraroma penentangan kepada penjajah Belanda dijadikan alasan untuk menggesernya. Ahmad kemudian dipandang persona non grata (sebagai subyek yang tidak dinginkan keberadaannya secara politik) oleh Raja Laiwui atas desakan pihak Belanda. Karena statusnya dipandang persona non grata, maka secara politis 
sosok Ahmad dilarang beresksistensi di Kendari dan sebagai konsekuensinya Ia harus diusir dan "deportasi" dari tempat keberadaannya, dengan jalan memindahkan yang bersangkutan ke Makassar pada tahun 1934 (Depdikbud:90).

Kepindahan Ahmad ke Makassar bukanlah akhir dari gerakan Muhammadiyah di Kendari, ibarat istilah pepatah "patah tumbuh hilang berganti", kendali organisasi yang ditinggalkan oleh Ahmad kemudian diambil alih oleh Danu Hasan dengan Sekretaris Muhammad Kasim Maddualeng. Meskipun Ahmad sebagai Ketua Muhammadiyah telah dipindahkan, namun aktivitas Muhammadiyah terus berjalan, khususnya pengajian yang secara rutin diselenggarakan. Muatan dakwah yang disemai dalam pengajian-pengajian tersebut fokus pada pemantapan ajaran Islam dan pengertian tentang kemerdekaan. Pembicara utama dalam setiap pengajian tersebut adalah Kasim Maddualeng dengan merujuk refernsi/buku: Pedoman Ringkas karya Bung Karno. Isi buku tersebut secara umum berisi tentang dua hal pokok. Pertama: Kita harus cinta bangsa dan cinta tanah air melebihi cinta kepada anak dan keluarga. Kedua: Kita sebagai umat Islam tidak sah keislaman kita jika tidak merdeka (Depdikbud:90).

Deskripsi di atas menggambarkan secara eksplisit bahwa betapa muatan dakwah Muhammadiyah yang digaungkan oleh kader-kadernya sangat kontekstual. Pembelajaran Islam melalui dakwah yang dikembangkan oleh anakanak panah Muhammadiyah tidak semata-semata menjajahkan Islam dari sisi ketaatan menjalankan aspek ritual dalam bentuk ibadah mahdah, seperti kewajiban menjalankan Sholat, menunaikan Puasa dan Zakat, plus naik haji bagi mereka yang mampu. Namun juga menyentuh aspek sosial politik yang sangat krusial untuk digaungkan pada masa tersebut yaitu keniscayaan membela kepentingan bangsa Negara dari gangguan penjajah. Melalui pengajian yang dibentuk oleh Muhammadiyah, kader-kader Muhammadiyah menyuntikan nilainilai Islam yang dipadu dengan keniscayaan bagi setiap muslim untuk mencintai tanah air dan bangsanya. Tema-tema dakwah yang mengusung muatan kesadaran nasionalisme yang digaungkan oleh kader Muhammadiyah pada masa itu, sekaligus membuktikan bahwa organ ini sejak awal mula menapakkan 
pengaruhnya di Sulawesi-Tenggara, telah berjasa besar dalam membentuk tatapikir masyarakat untuk memadukan antara ketaatan beragama dengan kesetiaan bernegara plus keniscayaan membentuk bangunan sosial politik kebangsaan yang terbebas dari belenggu penjajahan. Upaya mengangkat tematema sensitive seperti nasionalisme oleh kader-keder Muhammadiyah tentu saja didasarkan atas konteks tatanan sosial politik yang dialami oleh bangsa ini pada waktu itu, yang dipandang urgen untuk mencerahkan pemahaman masyarakat yang dihegemoni oleh kekuatan kolonial untuk segera sadar, bangkit dan keluar dari jebakan maut penjajahan Belanda. Pilihan tema Islam dan kebangsaan bukan tanpa resiko, namun karena didorong oleh semangat untuk keluar dari belenggu keterjajahan, maka hal tersebut dipilih oleh kader-kader Muhammadiyah dengan segala konsekuensi yang harus dihadapi. Dengan tekanan yang keras dari Belanda dan disebabkan kepindahan Ahmad Makkarausu dan kemudian disusul oleh M. Kasim Maddualleng ke Makassar, Muhammadiyah Kendari mengalami kemerosotan dalam kegiatan-kegiatan tabligh. Organisasi Muhammadiyah sendiri tidak pernah dibubarkan secara organisatoris sampai kedatangan Jepang. Para pengurus dan anggotanya bersikap membekukan kegiatan karena khawatir akan tindakan-tindakan tegas dari penjajah. Dan selanjutnya menyelenggarakan aktivitas yang bersifat klandestin (gerakan bawah tanah)(ibid).

\section{C.3. Membaca Gerakan Dakwah Muhammadiyah Pra Kemerdekaan}

Secara umum dimaklumi bahwa kondisi atau suasana sosial politik masa pra kemerdekaan bukanlah masa yang kondunsif bagi tumbuh kembangnya organisasi sosial kemasyarakatan seperti Muhammadiyah. Suasana sosial yang berada dibawah kendali dan hegomoni kekuasaan penjajah Belanda dan Jepang berimplikasi signifikan bagi gerak dan mobilitas roda organisasi. Kondisi dengan struktur kekuasaan politik yang tertutup diakui secara teoretis merupakan salah satu kendala utama bagi perkembangan sebuah gerakan sosial. Bagi pemerintah kolonial mengizinkan berdirinya berbagai gerakan sosial merupakan ancaman bagi eksistensi mereka di daerah jajahan, sehingga hampir dipastikan bahwa kalaupun sebuah organisasi diberi izin untuk beraktivitas, maka padanya akan 
diterapkan pengawasan melekat dan super ketat. Sebab membiarkan tumbuh kembangnya gerakan sosial yang diinisiasi oleh masyarakat, oleh penjajah dipandang atau sama dengan upaya memilihara dan membesarkan "macan" yang pada saatnya siap untuk menerkam pemeliharanya. Meski dengan pengawasan ketat, geliat sosial dari sekelompok orang untuk mengorganisir potensi dan kekuatan sosial tidak dapat dibendung sama sekali. Karena itulah melalui kebijakan akomodatifnya pemerintah Hindia Belanda kemudian mengizinkan sejumlah organisasi masyarakat tetapi dengan pengawasan yang super ketat. Demikianlah fakta sejarah yang diketahui oleh umum, bahwa sejumlah anak negeri karena didorong oleh tanggungjawab dan kesadaran untuk memberdayakan sesama anak bangsa kemudian menginisiasi pembentukan organisai masyarakat. Salah satu dari sekian organ yang lahir dan tumbuh masa sebelum kemerdekaan dan hingga kini wujudnya masih ada adalah Muhammadiyah yang didirikan oleh Ahmad Dahlan pada tahun 1912.

Pilihan Ahmad Dahlan untuk menjadikan Muhammadiyah sebagai organisasi sosial ketimbang organisasi politik oleh beberapa analisis sosial dipandang sebagai pilihan cerdas. Jika sekiranya Dahlan pada tahun 1912 memilih menjadikan Muhammadiyah sebagai organisasi sosial politik, maka sangat boleh jadi nama tersebut kini tinggal menjadi fosil yang hanya abadi dalam litertur sejarah tetapi eksistensinya kini tidak lagi kasat mata. Bergerak dalam ranah politik akan berimplikasi serius bagi kewaspadaan pihak penjajah, sedangkan memilih menjadikan Muhammadiyah sebagai organ sosial menjadikan Muhammadiyah sedikit leluasa bergerak sehingga dengan kecerdasan memainkan irama note dari gerakan Muhammadiyah perlahan tetapi pasti organ yang didirikan akan maju dan semakin maju mengiringi lintasan zaman. Hal tersebut terbukti bahwa setelah 1912 tahun dari mula keberadaannya, Muhammadiyah yang sebelumnya hanya diizinkan bergerak di areal tanah Jawa Dwipa perlahan tapi pasti meluaskan sayap pengaruhnya hingga ke Sumatera, kemudian merambah Pulau Sulawesi, Kalimantan dan akhirnya mengisi seluruh wilayah Nusantara. 
Pada tahun 1929/30 Muhammadiyah yang sangat gencar bergerak akhirnya merambah masuk ke wilayah Jazirah Tenggara pulau Sulawesi setelah terlebih dahulu menanamkan pengaruhnya di Sulawesi-Selatan. Dengan suasana bangsa yang sepenuhnya masih berada dibawa kendali penjajah Belanda tentu saja tidak mungkin membayangkan perkembangan Muhammadiyah pada waktu itu seperti yang tampak sekarang. Namun dengan sejumlah keterbatasan tersebut nilai-nilai Keislaman berprespektif Muhammadiyah dialirkan melalui relawan Muhammadiyah yang datang melintas samudera ke Sulawesi-Tenggara. Dengan tekad kuat dan penuh semangat anak panah Muhammadiyah yang datang dari berbagai daerah menghembuskan aura pengaruh positifnya ke wilayah ini, kendatipun dalam suasana struktur politik yang tertutup dan mengekang. Hal ini terbukti dengan terbentuknya Muhammadiyah di beberapa daerah SulawesiTenggara pada waktu itu. Secara teoretis dengan suasana struktur politik yang tertutup dan mengekang dipastikan gerakan Muhammadiyah tidak leluasa mendakwakan ide pembaruannya. Dengan mengusung tema dakwah amar makruf nahi mungkar, Muhammadiyah secara substansial ingin membangun nalar kritis masyarakat untuk tempil ke depan dan tidak diam atas segala fenomena sosial yang menyimpang dari garis lurus agama. Dan karena itulah, guna melanggengkan upaya dakwahnya di wilayah ini, eksponen Muhammadiyah "dituntut" untuk cerdas dan taktis dalam mengemas isu dakwah yang dijualnya. Pendekatan taktis dan strategis merupakan pilihan yang harus ditempuh oleh setiap gerakan sosial yang tumbuh dalam ruang sejarah yang terkooptasi oleh sturuktur sosial politik yang mengekang.

Jika merujuk pada penjelasan dalam data sejarah yang ada, jelas terlihat bahwa gerakan Muhammadiyah diframing sedemikian rupa oleh kader-kadernya sehingga kemudian dapat diterima oleh penduduk lokal. Gagasan kembali kepada Quran dan Sunnah sebagai orientasi utama yang tertuang dalam matan tujuan Muhammadiyah tentu saja merupakan menu utama dari jualan penggiat Muhammadiyah pada waktu itu. Bahwa selain mendasari dakwahnya untuk mengembalikan umat Islam pada kultur Quran dan Sunnah, Muhammadiyah juga mencanangkan cita-cita luhur untuk menjelmakan kehidupan sosial masyarakat 
yang hidup dalam kemakmuran dan keadilan yang dalam tujuan Muhammadiyah dibahasakan dengan mengadopsi konsepsi Quran: baldatun thayyibatun warabbun gafur. Dalam konteks dan ruang sosial era 1930-an cita-cita untuk mewujudkan baldatun thayyibatun warabbun gafur hanya akan terwujud jika bangsa Indonesia dapat mengendalikan bangsanya secara mandiri. Sebaliknya harapan untuk hidup adil makmur berpotensi hanya sebagai hayalan jika bangsa dan negeri ini masih tetap berada dibawah kendali penjajah. Sadar akan suasana tersebut para aktor gerakan Muhammadiyah era 1930-an selain melebarkan sayap persyarikatan di Bumi Anoa sekaligus membangunkan rasa nasionalisme penduduk setempat untuk bangkit melakukan perlawanan terhadap hegemoni penjajah. Integrasi nilai-nilai nasionalisme dalam tema dakwah eksponen Muhammadiyah dilakukan secara terstruktur dan sistematis dalam pengajianpengajian yang dilakukan dua kali sepekan.

Membingkai ide-ide keislaman dan nasionalisme dalam satu nafas dakwah yang dijalankan oleh anak-anak Muhammadiyah merupakan bentukan yang sengaja dibuat sebagai bagian taktik dan strategi pada masa itu. Model tersebut sangat kontekstual mengingat kebutuhan sosial pada masa itu adalah bagaimana umat Islam dapat menjalankan ajaran agamanya secara damai plus negeri tempat mereka berpijak juga harus aman dalam kuasa mereka. Karena itulah integrasi nilai-nilai Islam dengan semangat kebangsaan harus terus dialirkan guna membentuk tatapikir masyarakat yang sadar untuk bangkit melepaskan diri dari belenggu keterjajahan yang mereka alami. Dengan aktor-aktor dai Muhammadiyah pada waktu itu yang umumnya berpredikat sebagai guru, menjadikan aliran gagasan Islam dan nasionalisme yang dikampanyekan tampak berimplikasi positif, yaitu dengan berhasilnya Muhammadiyah menerobos masuk ke sejumlah daerah di Sulawesi-Tenggara. Posisi sebagai seorang guru pada masa itu menjadi sangat strategis untuk mempengaruhi sekaligus membentuk cara pandang masyarakat. Dengan memperhatikan tema dan buku-buku yang digunakan oleh dai Muhammadiyah pada era 30-an sebagaimana yang ditunjukkan oleh Muhammad Kasim Maddualleng, yaitu: Pedoman Ringkas karya Bung Karno serta Koran Berdasar Islam bersendi Kerakyatan yang dipimpin oleh 
M. Ishak dan Firdaus terlihat jelas bagaimana eksponen Muhammadiyah membingkai (framing) ide-ide Islam revolosioner, dan mengajak masyarakat untuk membangun jiwa keagamaan plus nasionalisme. Karena dakwah yang cenderung keras tersebut maka sejumlah dai Muhammadiyah mendapat pengawasan yang sangat ketat dari Belanda (Hasbullah, 1995:95)(ibid).

Dalam konteks tersebut, upaya kuat mengemas gagasan revoluisoner untuk diinternalisasikan dalam cara berpikir masyarakat Kendari oleh dai Muhammadiyah "berbuah" sanksi bagi penggiat dakwah tersebut. Kasim maupun Ketua Muhammadiyah pada waktu itu, dimutasi paksa oleh Pemerintah Belanda ke Makassar (1934). Hal ini sekaligus menunjukkan bahwa struktur politik yang tertutup menjadi kendala signifikan bagi anak-anak Muhammadiyah untuk bisa mengalirkan dan mengembangkan gagasan Muhammmadiyah, sehingga penggiatpenggiat Muhammadiyah yang disebutkan tadi dengan sangat terpaksa tidak dapat melanjutkan kegiatannya. Namun sama sekali tidak berarti Muhammadiyah hilang dari peradaban dan sejarah masyarakat di wilayah ini. Sebagai strategi untuk menghindari intimidasi sebagaimana yang dialami oleh pendirinya di Kendari, Muhammadiyah membekukan diri hingga pada saatnya terlihat kembali aktivitasnya.

Kendatipun kemudian diketahui bahwa pasca dipindahkannya beberapa tokoh utama Muhammadiyah dari Kendari ke Makassar oleh pemerintah Hindia Belanda, aktivitas Muhammadiyah di Kendari mulai memudar, namun tidak berarti organisasi ini kemudian beku secara berkelanjutan. Residu Muhammadiyah tetap tertinggal dan kemudian kembali menemui bentuknya pada masa setelah kemerdekaan. Pertanyaan mengapa Muhammadiyah membekukan diri pasca kepindahan tokoh-tokoh penggeraknya, penting untuk dijelaskan. Secara teoretis ruang struktur politik yang berkembang pada masa itu tampak tidak semakin kondusif. Karenanya langkah-langkah taktis strategis perlu diambil untuk menyelamatkan organisasi dan anggotanya, sehingga menjalankan misi secara "terselubung" menjadi salah satu pilihan yang ditempuh oleh Muhammadiyah. Ini berarti terjadi perubahan pola dakwah yang dilakukan, dari semula melakukan penentangan secara terang-terangan, menjadi pola dakwah 
yang bersifat rahasia. Terjadinya pergeseran pola dakwah yang semula dilakukan secara transparan menjadi lebih tertutup, memungkinkan terjadi karena tiga hal: 1). Sejak mula keberadaannya Muhammadiyah melakukan rekruitmen kader yang sangat selektif. Realitas ini memungkin bagi Muhammadiyah untuk tetap eksis sekalipun dengan cara "rahasia" sebab pola rekruitmen yang ketat berpotensi melahirkan kader persyarikatan yang militant. 2). Sejumlah kader inti atau yang berada dalam struktur kepengurusan adalah merupakn tokoh lokal atau putra daerah Sulawesi-Tenggara. Salah satu diantaranya adalah Iwana yang menurut kesaksian Ahmad Aljufri tokoh ini tetap eksis hingga masa kemerdekaan. 3). Militansi kader persyarikatan selain terbentuk oleh pola rekruitmen dan sistem pengkaderan yang selektif, juga adanya tuntutan sosial budaya politik pada waktu itu yang meniscayakan para anggota Muhammadiyah untuk mendorong kebangkitan nasional di Kendari. Dengan demikian, kendatipun eksistensi dan tumbuh kembang gerakan dakwah Muhammadiyah terkendala atau terhambat karena berada dalam ruang struktur kesempatan politik yang tertutup, sehingga memaksa gerak persyarikatan dilakukan secara diam-diam untuk menghindari benturan atau konflik terbuka dengan pihak Belanda. Namun keberhasilan Muhammadiyah memobilisasi sumber daya melalui rekruitmen yang dilakukannya serta kecerdasan elemen Muhammadiyah membangun narasi dakwah tentang urgensi kemerdekaan bagi umat Islam yang ditransmisikan melalui pengajian (mungkin secara berulang) menjadi bekal berharga dan panduan bagi anak-anak panah persyarikatan dalam melanjutkan dakwah Muhammadiyah, kendatipun dilakukan dalam ruang yang senyap.

\section{C.4 Membangun Kesadaran Nasional Lewat Dakwah}

Kehadiran Muhammadiyah yang lebih awal 33 tahun dari Indonesia, menjadikan warga persyarikatan paham betul tentang arti penting kemerdekaan bagi suatu bangsa. Selain itu doktirn amar makruf nahi mungkar yang dijadikan sebagai salah satu prinsip bertindak warga Muhammadiyah dalam melakukan rekayasa sosial, meniscayakan setiap elemen aktivis Muhammadiyah peka terhadap segala bentuk penindasan dan penistaan terhadap nilai-nilai kemanusian. 
Karena itulah amar makruf nahi mungkar menjadi misi berkelanjutan, tanpa henti dalam rekam jejak sejarah Muhammadiyah (SM,2016). Dalam konteks masa pra kemerdekaan maka salah satu bentuk amar makruf yang dijalankan oleh Muhammadiyah adalah membangun pemahaman Islam berwawasan kebangsaan dalam rangka membangkitkan kesadaran nasional. Tema tersebut menjadi sangat penting, dalam rangka mendidik masyarakat untuk bersatu padu, bahu membahu mendorong percepatan Indonesia berdaulat. Gerakan inilah yang tampak eksplisit diperankan oleh Muhammadiyah di Kendari pada tahun 1929-1934. Ada tiga indikator yang dapat membuktikan bahwa aktifitas dakwah Muhammadiyah pada masa itu benar-benar mengusung tema nasionalisme dalam arti untuk membangkitkan kesadaran berbangsa dan bertanah air Indonesia.

Pertama: dari sudut pilihan tema atau materi-materi pengajian yang digulirkan oleh elemen Muhammadiyah, secara terang benderang menunjukkan bahwa dai-dai Muhammadiyah sedang menegosiasikan gagasan Islam dan Nasionalisme. Hal ini ditunjukkan paling tidak dengan referensi utama yang dijadikan sebagai sumber rujukan dalam pengajian. Yaitu: yaitu: Pedoman Ringkas karya Bung Karno, serta Koran Berdasar Islam bersendi Kerakyatan. Kedua: dari sisi karakter aktor penggerak dalam hal ini khususnya Ahmad Makkarausu Dg. Ngilau sebagai Ketua Muhammadiyah pada saat itu. Sosok Dg. Ngilau dikenal sebagai subyek yang anti terhadap penjajahan. Rekam jejak sejarah hidupnya menunjukkan bahwa dimanapun sosok ini bereksistensi, disitu dakwah Muhammadiyah dan gerakan perlawanan terhadap Belanda disuarakan (Khittah,2016). Realitas tersebut sebagai fakta penguat bahwa gerakan dakwah Muhammadiyah di Kendari pada masa awal mengusung tema kebangkitan Nasional, selain karena doktrin amar makruf nahi mungkar juga karena militansi penggeraknya. Ketiga: realitas pengawasan Belanda atas aktivitas tabligh Muhammadiyah secara tersirat mengindikasikan adanya materi-materi pengajian yang tidak bersetuju dengan aktivitas yang dijalankan oleh kolonial Belanda (Hasbullah, 1995:95). Oleh karena aktivitas dakwah Muhammadiyah yang dijalankan oleh dai Muhammadiyah dipandang sangat berbahaya, maka pihak 
Belanda memberikan status persona non grata terhadap tokoh utama Muhammadiyah. Fakta ini secara eksplisit menunjukkan jika tokoh-tokoh utama Muhammadiyah melancarkan penentangan kepada Belanda. Wujud penentangan tersebut salah satunya dijalankan oleh elemen Muhammadiyah dengan menyuntikkan materi dan wawasan kebangsaan pada masyarakat melalui kegiatan tabligh yang dilakukannya. Keempat:selain tiga fakta di atas, yang tidak kala pentingnya adalah pengakuan tertulis yang termuat dalam dokumen Sejarah Kebangkitan Nasional Daerah Sulawesi Tenggara, secara eksplisit menyebutkan ada tiga kekuatan organisasi sosial yang bergerak membangkitkan rasa nasionalisme dan perlawanan terhadap penjajah Belanda di Sulawesi-Tenggara. Yaitu Muhammadiyah, PSII dan Parindra. Dari tiga elemen sosial tersebut, hanya Muhammadiyah yang merupakan elemen sosial murni atau tidak berafiliasi pada partai politik, sedangkan dua lainnya yaitu PSII dan Parindra adalah organisasi sosial politik/partai politik (Depdikbud:88-100).

\section{Penutup}

Keterlibatan aktif elemen Muhammadiyah dalam membangkitkan semangat nasionalisme di Kendari pada masa pra kemerdekaan, selain sebagai tanggungjawab sosial warga Muhammadiyah selaku bagian tak terpisahkan dari rakyat Indonesia, juga tidak dapat dilepaskan dari doktrin persyarikatan yang mengejawantah dalam visi misi organisasi Muhammadiyah, yaitu sebagai organisasi dakwah amar makruf nahi mungkar. Doktrin inilah yang menjadi fondasi tumpuan berpijak elemen persyarikatan dalam mentransmisikan gagasan kebangkitan nasional di Kendari melalui gerakan dakwah dan tabligh yang terorgansir.

Giat mengalirkan semangat Islam dan nasionalisme oleh aktor-aktor Muhammadiyah pada mulanya dilakukan secara terang-terangan. Namun dalam perkembangan lebih lanjut, khususnya ketika tokoh utama penggerak Muhammadiyah diberi status persona non grata oleh pihak colonial, maka gerakan dakwah Muhammadiyah selanjutnnya dilakukan secara klendestin (gerakan bawah tanah). Pendekatan terakhir ini ditempuh mengingat ruang 
struktur politik pada masa pra kemerdekaan yang dikuasai oleh kolonial bersifat tertutup dan hegemonik, sehingga kurang kondusif untuk "menularkan" ide-ide nasionalisme kepada masyarakat atau subyek dakwah secara terbuka.

Perjalanan dan peran dakwah Muhammadiyah di Kendari berdasarkan rekam jejak sejarah yang ditorehkan oleh aktor-aktor persyarikatan Muhammadiyah (1929-1934) menunjukkan pada fakta bahwa Muhammadiyah adalah salah satu elemen penting pengalir gagasan kebangsaan dalam rangka membangkitkan kesadaran Nasionalisme dan perlawanan terhadap penjajah di Kendari. Pengakuan atas peran signifikan gerak dakwah Muhammadiyah dalam menanamkan kesadaran Nasionalisme di Kendari secara obyektif tercatat dalam dokumen sejarah kebangkitan nasional.

\section{Referensi}

Ahmal, "Muhammadiyah dalam Perjuangan Kemerdekaan di Kampar", Jurnal Ilmu-Ilmu Sejarah, Budaya dan Sosial, Jurnal Lentera, 6 (15), 2015

Alfian, Kaum Modernis, Perlawanan Muhammadiyah Terhadap Kolonialisme Belanda. Yogyakarta: GajahMada Univeersity Press, 2010

Asmara ,Dedi, "Muhammadiyah Sumatera Barat (1925-1950)”, Jurnal Analisis Sejarah, 5 (1), 2016, h.46

Benfoord, Robert, "Framing Process and Socila Movement: An Over view and Assesment" dalam Annual Reiview of Sociology, 2000.

Depdikbud, Sejarah Kebangkitan Nasional Daerah Sulawesi-Tenggara, Jakarta:

Depdikbud,

1979

Graaf, H. J. de "'South Asian Islam to the Eighteent Century" dalam , P.M. Holf (ed.),Cambridge History of Islam, j1 II, London : The Cambridge University Press, 1970

Hasbullah, Sejarah Pendidikan Islam di Indonesia, Jakarta: RajaGrafindo Persada, 1995 
Ricklefs, MC. Sejarah Indonesia Modern, Yogyakarta: UGM Press, 2005

Sadik, Jafar, "Dinamika Muhammadiyah di Sumatera Utara", Journal of Contemporary Islam and Society, 1 (1), 2017

Muhammadiyah, Suara, Kontekstualisasi Doktrin 'Amar ma'ruf nahi munkar' 18 January, 2016

Khittah, Biografi KH. Ahmad Makkarausu Amansyah Dg. Ngilau (Pimpinan Muhammadiyah Sulawesi-Selatan 1975-1978), 15-4-2016

Kriesi, Hanspeter'Political Context and Opportunity, dalam Blackwel Companion to Social Movement, Massachusets : Blackwell Publishing 2004

Munsond, Said, Islamic Mobilization: Social Movement Theory and the Egyptian Muslim Brotherhood, Journal The Sociological Quarterly/ Vol. 42, 2001issue 4, Published online: 12 Dec 2016

Munawir ,Ahmad Warson, Kamus al-Munawir, Jakarta: Pesantren al-Munawir, 1984

Nashir, Haedar, "Muhammadiyah Melangkah Kedepan”, dalam Suara Muhammadiyah, 07 November 2018

Noer,Deliar, Gerakan Modern Islam di Indonesia, Jakarta: PT Pustaka LP3ES, Cet VIII, 1996

Notosusanto ,Nugroho, Masalah Penelitian Sejarah Kontemporer : Suatu Pengantar, Jakarta : Yayasan Idayu, 1978

Opp, Karl Dieter, Theory of Political Protest and Social Movement: a Multidiciplinary Introduction, Critique and Synthesis , London: Routhledge, 2009

Ricklefs, MC. Sejarah Indonesia Modern, Yogyakarta: UGM Press, 2005

Sadik, Jafar, "Dinamika Muhammadiyah di Sumatera Utara", Journal of Contemporary Islam and Society, 1 (1), 2017

Snow, David, "Framing Process, Ideology and Discursive Fileds dalam Blackwel Companion to Social Movement, Massachusets : Blackwell Publishing 2004 Tilly, Charless, From Mobilization to Revolution. London: Edison Publishing, 1978 
Wiktorowicz, Quintan (ed.), dalam A Islamic Activism, A Social Movement Theory, Bloomington dan Indianapolis, Indiana University Press, 2004, h. 21

"Anatomy of the Salafi Movement", dalam Jurnal Studies in Conflict an Terrorism, 2006, vol.29 